Adriana Pogoda-Kołodziejak

Siedlce

\title{
FUNKCJONOWANIE I DZIAŁALNOŚĆ ZAKONU KRZYŻACKIEGO ORAZ STOWARZYSZENIA ŚWIECKICH FAMILIARES W PIERWSZEJ DEKADZIE XXI WIEKU
}

Zakon Braci i Sióstr Domu i Szpitala Niemieckiego Najświętszej Marii Panny $w$ Jerozolimie funkcjonuje $\mathrm{w}$ dniu dzisiejszym jako Zakon Niemiecki zajmujący się szeroką działalnością charytatywną, wychowaniem chrześcijańskim dzieci, młodzieży i dorosłych oraz opiekuje się chorymi, starszymi i biednymi ludźmi. Oficjalna nazwa zakonu brzmi: Frater domus hospitalis sanctae Mariae Teutonicorum in Jeruzalem, Brüder vom Deutschen Haus St. Mariens zu Jeruzalem, w skrócie: Der Deutsche Orden ${ }^{1}$. Jest to nawiązanie do pierwszej nazwy Zakonu Orden des Hospitals zu Sankt Marien der Deutschen in Jeruzalem, która została przejęta od funkcjonującego na podstawie rozporządzenia papieża Celestyna II z dnia 9 grudnia 1143, szpitala Joanitów w Jeruzalem².

Po sekularyzacji własności zakonnej w Prusach w 1525 r. i w Inflantach w 1561 r. Krzyżacy dokonali reorganizacji Zakonu w Rzeszy³. Zakon Krzyżacki stracił znaczenie organizacji politycznej i zaczął pełnić funkcję zakonu religijnego ${ }^{4}$. Już w XIV w. wielkie terytoria zakonne były usamodzielnione, co spowodowało problem w wyborze następcy Alberta. Na czele Zakonu stanął krajowy niemiecki mistrz z Mergentheim w baliwacie wirtemberskim,

${ }^{1}$ M. Tumler, A. Udo, Der Deutsche Orden. Von seinem Ursprung bis zur Gegenwart, Bonn 1974, s. 95.

${ }^{2}$ F. Kurowski, Der Deutsche Orden. 800 Jahre ritterliche Gemeinschaft, Hamburg 1997, s. 18 .

${ }^{3}$ H. Boockmann, Zakon Krzyżacki, Gdańsk/Warszawa 2002, s. 167-168.

${ }^{4}$ J. Tyszkiewicz, K. Mórawski, Krzyżacy, Warszawa 1973, s. 265. 
który w 1528 r. otrzymał godność księcia Rzeszy5. Na podstawie małej liczby dokumentów z tego okresu można jednak przypuszczać, że wielki mistrz niemiecki w Rzeszy miał na tyle silną pozycję, iż nie musiał być podporządkowany wielkiemu mistrzowi Zakonu Niemieckiego ${ }^{6}$. W 1526 r. Walter von Cronberg został wybrany na administratora urzędu wielkiego mistrza i uznany przez Rzeszę za tymczasowego zwierzchnika Zakonu ${ }^{7}$. Akty prawne z lat 1529-1530 nie rozwiązały problemu podporządkowania dóbr zakonnych wielkiemu mistrzowi. Baliwat alzacko-burgundzki oraz zakonnicy ze Szwabii rościli sobie prawo do wyboru komtura krajowego ${ }^{8}$. Oprócz chaosu w funkcjonowaniu Zakonu pojawił się problem przechodzenia zakonników na nową wiarę oraz wywłaszczanie majątków zakonnych. Mimo tych przeciwności Zakon, pogodzony z utratą Prus i Inflant, dokonał konsolidacji i reorganizacji ${ }^{9}$ "Najlepiej widać to po rozbudowie frankońskiego komturstwa Mergentheim do rangi rezydencji wielkiego mistrza i stolicy ziem podległych bezpośrednio wielkiemu mistrzowi, jak również - do pewnego stopnia - centrum Zakonu"10. Pod koniec XVI w. istniało jeszcze 12 prowincji krzyżackich: Alzacja, Lotaryngia, Turyngia, Hesja, Koblencja, Frankonia, Alten-Bisen, Austria, Westfalia, Bolzano i Utrecht, który w wyniku szerzenia się protestantyzmu przestał być prowincją w $1637 \mathrm{r}^{11}$ Po katolickiej reformie w drugiej połowie XVI wieku, w której Zakon miał swój udział, zostało otwarte w 1606 r. w Mergentheim seminarium duchowne ${ }^{12}$, rycerze zwani Ordenskavaliere zaczęli zaś brać udział w wojnach $\mathrm{z}$ muzułmanami ${ }^{13}$. Zakon próbował również odzyskać Żmudź po pierwszym rozbiorze Polski w 1772 r. i wnosił pretensje do Prus i Inflant ${ }^{14}$. Od $1641 \mathrm{r}$. na czele Zakonu stawali członkowie rodziny cesarskiej, a urząd wielkiego mistrza stał się ponownie "godnością równą książętom Kościoła, obejmowaną przez członków rodzin książęcych Rzeszy stanu duchownego [... $]^{\prime \prime 15}$. W 1788 r. w Zakonie Krzyżackim było „10 landkomturów, którzy zarządzali baliwatami, 59 komturów, którzy zarządzali majątkami, i 27 rycerzy zwykłych. Przyjmowano do Zakonu

5 Ibidem, s. 265-266.

${ }^{6} \mathrm{H}$. Boockmann, op. cit., s. 167.

7 Ibidem, s. 169.

${ }^{8}$ Ibidem, s. 169-170.

${ }^{9}$ Ibidem, s. 170-171.

${ }^{10}$ Ibidem, s. 171.

${ }^{11}$ J. Tyszkiewicz, K. Mórawski, op. cit., s. 267.

${ }^{12}$ H. Boockmann, op. cit., s. 172.

${ }^{13}$ K. Górski, Zakon Krzyżacki a powstanie państwa pruskiego. Wrocław/Warszawa/ Kraków/Gdańsk 1977, s. 219.

14 Z. Kowalska, Krzyżacy w innym świetle. Od Średniowiecza do czasów wspótczesnych, Wien/Tarnów 1997, s. 59.

${ }^{15} \mathrm{H}$. Boockmann, op. cit., s. 173. 
nie bez trudności, rycerz musiał przedstawić 16 przodków szlachty (16 quartiers). W Zakonie było 71 księży, ale żadnych braci służebnych ani zakonnic"16. Objęcie urzędu wielkiego mistrza przez syna Marii Teresy, Franciszka Maksymiliana, doprowadziło do udziału Zakonu w polityce rodziny Habsburgów i w przeobrażeniach ustrojowych w Rzeszy w 1801 r. ${ }^{17} \mathrm{~W}$ tym samym roku przestały istnieć prowincje w Koblencji i Lotaryngii $^{18}$. Od 1805 r. godność wielkiego mistrza była dziedziczona przez członków domu Habsburgów ${ }^{19}$ z krótkimi przerwami do $1923 \mathrm{r}^{20}$

W 1809 r. Napoleon rozwiązał Zakon Niemiecki, zabierając jego własnośćc ${ }^{21}$. Bractwo zakonne istniało nadal, a po śmierci rządzącego od $1804 \mathrm{r}$. Antoniego Wiktora, który w 1809 roku w Wiedniu ustanowił siedzibę Zakonu, przenosząc tam skarbiec i archiwum ${ }^{22}$ urząd wielkiego mistrza objął arcyksiążę Maksymilian Józef, który zreorganizował Zakon nadając mu nową nazwę - Der Deutsche Ritterorden, czyli Niemiecki Zakon Rycerski ${ }^{23}$. Papież zaaprobował w 1837 r. plany zakonne. 26 lutego 1839 r. kapituła zaakceptowała statuty zakonne, a w 1840 r. ogłoszono restytucję Niemieckiego Zakonu Rycerskiego i jego prawnopaństwowy status ${ }^{24}$. W połowie XIX w. Zakon jako korporacja szlachecka zajmował się opieką nad chorymi i rannymi w czasie wojny i miał dwa szpitale, jeden we Freudenthalu, drugi zaś w Opawie ${ }^{25}$. Zakon cieszył się w tym czasie uznaniem, o czym świadczy to, że „w katalogu z 1914 r. wśród sympatyków Zakonu odnotowano 46 członków rodziny królewskiej i 1353 przedstawicieli rodów królewskich $^{26}$. Po rozpadzie monarchii austro-węgierskiej w 1918 r. funkcjonowanie Zakonu było zagrożone, a jego egzystencję uratowało uznanie go za instytucję wyłącznie kościelną ${ }^{27}$. Ostatnim wielkim mistrzem rycerzem był arcyksiążę Eugeniusz i od reformy zakonnej w 1923 r. nie było już nowych rycerzy wśród Krzyżaków. Po okupacji Austrii w 1938 r. Adolf Hitler skasował Zakon Niemiecki ${ }^{28}$. Hitlerowcy chcieli wykorzystać Zakon i jego historię do celów propagandowych, próbując stworzyć nowy Zakon

16 K. Górski, op. cit., s. 219.

${ }^{17} \mathrm{H}$. Boockmann, op. cit., s. 174.

${ }^{18}$ J. Tyszkiewicz, K. Mórawski, op. cit., s. 267.

${ }^{19}$ K. Górski, op. cit., s. 219.

${ }^{20}$ Z. Kowalska, op. cit., s. 57.

${ }^{21}$ H. Boockmann, op. cit., s. 174.

22 Z. Kowalska, op. cit., s. 60.

${ }^{23}$ H. Boockmann, op. cit., s. 175.

${ }^{24}$ Z. Kowalska, op. cit., s. 61.

25 J. Tyszkiewicz, K. Mórawski, op. cit., s. 267.

26 Z. Kowalska, op. cit., s. 63.

${ }^{27}$ Ibidem, s. 63-64.

${ }^{28}$ K. Górski, op. cit., s. 220. 
Niemiecki oparty na nazistowskich założeniach ${ }^{29}$. Po II wojnie światowej nie doszło do restytucji we wszystkich państwach, w których funkcjonował Zakon, gdyż w Czechosłowacji i Jugosławii dobra zakonne zostały przejęte przez komunistów, a działalność została zakazana. Odrodzenie Zakonu w tych państwach nastąpiło dopiero po 1989 r. ${ }^{30} \mathrm{~W} 1946 \mathrm{r}$. do rąk Zakonu powróciła stolica w Wiedniu ${ }^{31}$.

Reguły funkcjonowania dzisiejszego Zakonu Krzyżackiego zostały zatwierdzone przez Kongregację Instytutów Życia Konsekrowanego i Stowarzyszeń Życia Apostolskiego w dniu 11 października 1993 roku w Rzymie i są zgodne z normami Kodeksu Prawa Kanonicznego oraz wskazaniami Soboru Watykańskiego II ${ }^{32}$.

Wyboru wielkiego mistrza, którego główną siedzibą jest Wiedeń, dokonuje zbierająca się co sześć lat kapituła generalna zakonu w skład której wchodzą: „,aktualnie urzędujący wielki mistrz, były wielki mistrz - jego poprzednik, radcy generalni, prokurator generalny, ekonom generalny, przeorzy, po jednym delegacie z prowincji zakonnych, wybrana przez kapitułę siostra - asystentka generalna, siostry przełożone prowincji i po dwie siostry wydelegowane przez kapituły prowincjonalne ${ }^{\prime \prime 33}$.

Katolicki Zakon składa się z dwóch zgromadzeń: braci i sióstr. Obok braci duchownych mających święcenia kapłańskie funkcjonują również bracia świeccy, którzy ich nie posiadaja, jak również bracia oblaci. Wszyscy bracia zobowiązani są do składania ślubów wieczystych, które poprzedzone są następującymi etapami: postulat, jednoroczny nowicjat, pierwsze śluby. Noszą oni tradycyjny czarny strój zakonny z charakterystycznym krzyżem Zakonu Niemieckiego na piersi ${ }^{34}$.

W Regułach Zakonnych krzyż ten oznacza: „Pod tym Znakiem Boża miłość chce pomóc ludziom i doprowadzić ich do Chrystusa. Dla nas ten Krzyż jest siłą i potęgą w życiu, pociechą i wiarą w umieraniu, honorem i sławą na wieki" ${ }^{\prime 35}$. Na ich czele stoją wybierani co trzy lata przeorzy wspomagani przez dwóch radców i ekonoma prowincjalnego. Przeor oraz rada prowincji wyznacza na trzy lata braci superiorów, którzy zarządzają poszczególnymi domami zakonnymi ${ }^{36}$.

${ }^{29}$ Z. Kowalska, op. cit., s. 65.

${ }^{30}$ Ibidem, s. 65.

${ }^{31}$ F. Kurowski, op. cit., s. 346.

${ }^{32}$ Z. Kowalska, op. cit., s. 7.

${ }^{33}$ Ibidem, s. 69.

${ }^{34}$ M. Tumler, A. Udo, op. cit., s. 96.

${ }^{35}$ In der Regel des Ordens heißt es: „Unter diesem Zeichen der Liebe Gottes wollen wir den Menschen helfen und sie zu Christus führen. Uns sei das Kreuz Kraft und Stärke im Leben, Trost und Zuversicht im Sterben, Ehre und Ruhm in alle Ewigkeit", http://www. deutscher-orden.at, 05 listopada 2012.

${ }^{36}$ Z. Kowalska, op. cit., s. 70. 
Zgromadzenie Braci Zakonu Niemieckiego funkcjonowało do roku 1991 w czterech prowincjach: niemieckiej, austriackiej, włoskiej, słoweńskiej. W 1991 powstała prowincja czesko-słowacka ${ }^{37}$.

Prowincja Braci Zakonu w Niemczech składa się z 5 konwentów: Darmstadt, Wetter, Frankfurt am Main, Maria Birnbaum i Weyarn, gdzie znajduje się główna siedziba przeora, którym aktualnie jest Norbert Thü $x^{38}$.

Zakonnicy pełnią posługę zarówno w parafiach jak i w placówkach socjalnych znajdujących się w okolicznych miejscowościach. Parafie zakonne w Austrii znajdują się w Wiedniu-Schottenfeld, Spannbergu, Paltendorfie, Gumpoldkirschen, Velm-Götzendorf i Friesach ${ }^{39}$, których głównym przeorem jest Johannes Kellner ${ }^{40}$. Lana, na czele z przeorem Peterem Lantschnerem ${ }^{41}$, jest siedzibą konwentu prowincji włoskiej w północnym Tyrolu, w skład której wchodzą parafie w Gargazon, Völlan, St. Leonhard, Oberinn-Ritten, Wangen-Ritten, Unterinn-Rittern, Lengmoos-Rittern, Siebeneich, Sarntheim, nowicjat w Bozen i siedziba prokuratury generalnej oraz „Dom Pielgrzyma” w Rzymie ${ }^{42}$. W Słowenii, nad dziesięcioma parafiami: Melika Nadejla, Gradem Podzemlj, Metlika, Semic, Sinica, Serdisce ob Dravi, Ormoz, Miklavz pri Ormozu ${ }^{43}$, opiekę duszpasterską sprawują bracia pod przewodnictwem przeora Janko Štampara ${ }^{44}$. Przeor Dariusz Cecerski ${ }^{45}$ prowadzi prowincję czeską z siedzibą główną w Opawie ${ }^{46}$.

Strój zakonny i białe nakrycie głowy oraz krzyż Zakonu noszony na czarnym sznurze na szyi to symbol zgromadzenia sióstr. Składają one śluby na okres pięciu lat po półrocznym postulacie i rocznym nowicjacie. Siostry podlegają najwyższej przełożonej w danej prowincji ${ }^{47}$, która wspierana jest przez siostrę ekonomkę prowincjalną oraz przez dwie lub cztery siostry tworzące radę i wchodzące $w$ skład kapituły prowincjonalnej. Zgromadzenie Sióstr Zakonu Niemieckiego w Niemczech ma swoją siedzibę główną w Passau a siostra przełożoną jest Mirjam Müller, zaś w Austrii ich dom na czele z siostrą Monika Madleniger znajduje się w Friesach. W prowincji czesko-słowackiej siostry mają swoją siedzibę, w Opawie, a siostrą przełożoną jest Petra Daňová, we Włoszech mają dom w Lanie, na

\footnotetext{
${ }^{37}$ Ibidem, s. 71-73, http://www.deutscher-orden.at, 05 listopada 2012.

${ }^{38}$ http://www.deutscher-orden.at, 05 listopada 2007, 11 listopada 2012.

${ }^{39}$ Z. Kowalska, op. cit., s. 71.

${ }^{40} \mathrm{http}: / /$ www.deutscher-orden.at, 05 listopada 2012.

${ }^{41}$ Ibidem.

${ }^{42}$ Z. Kowalska, op. cit., s. 71-73.

${ }^{43}$ Ibidem, s. 73.

${ }^{44} \mathrm{http}: / /$ www.deutscher-orden.at, 05 listopada 2012.

${ }^{45}$ Ibidem.

${ }^{46}$ Z. Kowalska, op. cit., s. 73.

${ }^{47}$ M. Tumler, A. Udo, op. cit., s. 96.
} 
czele którego stoi Hiltraud Unterkalmsteiner, zaś w Słowenii wraz z siostrą przełożoną Mirjam Belaj mieszkają w Ljutomer ${ }^{48}$.

W Passau siostry prowadzą Akademię Pedagogiki Socjalnej, w której to, w przeciągu 2 lat, można zdobyć wykształcenie wychowawcy dziecięcego i młodzieżowego oraz pracownika z osobami niepełnosprawnymi ${ }^{49}$.

Zakon zajmuje się również kształceniem dzieci i młodzieży. Posiada w Czechach, w miejscowości Olmütz, prężnie działające Gimnazjum Zakonne $^{50}$. Od roku 2007 funkcjonuje ono pod nazwą Kirchliches Gymnasium des Deutschen Orden ${ }^{51}$. Zakon Niemiecki ma w Troppau, w Czechach, swoje konserwatorium muzyczne, które w 2008 roku obchodziło swoje dziesięciolecie ${ }^{52}$.

Równocześnie funkcjonuje także stowarzyszenie świeckich tzw. Familiaren, związanych z zakonem przyrzeczeniem bez obowiązku składania ślubów zakonnych ${ }^{53}$. Do ich grona zalicza się zarówno świeckich jak i duchownych, którzy poprzez modlitwę i działalność charytatywną wspierają założenia Zakonu ${ }^{54}$. „Nowo przyjęci otrzymują czarny płaszcz z szyldem zakonnym i krzyż Zakonu, zawieszany na szyi. Szczególnie zasłużeni dobrodzieje Zakonu przyjmowani są do grona rycerzy honorowych; oznaką tej godności jest biały płaszcz i krzyż Zakonu zawieszany na szyi"55. W roku 1997 było to 9 osób $^{56}$. Stowarzyszenie to zostało powołane do życia pod przewodnictwem Kardynalnego Protektora Josefa Wendela w roku 1957. Otrzymało ono nazwę Verein der Freunde und Förderer des Deutschen Ordens St. Mariens zu Jerusalem ${ }^{57}$. W roku 1965 papież Paweł VI. powołał do życia Familiareninstitut, dokonując w ten sposób dokładnej strukturyzacji stowarzyszenia. Wszelkie decyzje dotyczące zgromadzenia podejmowane są przez delegatów baliwatów i Komturii Rzymskiej ${ }^{58}$. Hasłem stowarzyszenia jest hasło Zakonu „Pomagać, zbawiać, bronić” ${ }^{59}$. Zgodnie z nim członkowie prowadzą działalność charytatywną na terenach swo-

${ }^{48} \mathrm{http}: / /$ www.deutscher-orden.at, 05 listopada 2012.

${ }^{49}$ http://www.faks-passau.de, 5 listopada 12.

${ }^{50}$ Gimnazjum Zakonne ma swoją siedzibę w centrum miasta, w pięknym pałacu odbudowanym na początku XX wieku przez arcyksięcia Eugena z Habsburgów, Wielkiego Mistrza Zakonu Niemieckiego.

${ }^{51} \mathrm{http} / / /$ www.deutscher-orden.de, 15 listopada 2012.

${ }^{52}$ Ibidem.

${ }^{53}$ Z. Kowalska, op. cit., s. 7.

${ }^{54}$ M. Tumler, A. Udo, op. cit., s. 97.

${ }^{55}$ Z. Kowalska, op. cit., s. 69.

56 Ibidem, s. 75.

${ }^{57}$ F. Kurowski, op. cit., s. 348.

58 Z. Kowalska, Krzyżacy w innym świetle. Od Średniowiecza do czasów współczesnych, Wien/Tarnów 1997, s. 69.

59 „Helfen, Heilen, Wehren”, http://deutscher-orden.de, 11 listopada 2012. 
ich baliwatów, dbają o rozwój wiary i bronią swojej społeczności przed negatywnymi wpływami zagrażającymi chrześcijańskiemu światopoglądowi. Ich podstawą jest wiara chrześcijańska i kościół katolicki oraz spuścizna Zakonu Niemieckiego. Familiaren funkcjonują na terenach Niemiec, Austrii, Włoch, Czech i Belgii w stworzonych przez siebie komturiach. Liczba członków Familiaren stale rośnie w bardzo szybkim tempie, a na dzień dzisiejszy wynosi 420 członków ${ }^{60}$. W październiku 2009 roku odbyła się uroczysta inwestytura stowarzyszenia w Bambergu. Przybyło około 400 członków Zakonu. Familiaren muszą prowadzić swoje życie w sposób nienaganny i cieszyć się dobra opinią. Nowo przyjęci otrzymują płaszcze, krzyże i różańce na znak przyjęcie do wspólnoty Chrystusa ${ }^{61}$. Zakon oczekuje od członków zasług na jego rzecz.

Baliwat niemiecki z siedzibą we Frankurcie nad Menem składa się z 9 komturii: An Isar, Lech und Donau, An der Donau, Franken, Am Oberrhein, An Tauber, Neckar und Bodensee, An Rhein und Main, An Rhein und Ruhr, An Weser und Ems und An Elbe und Ostsee. Obok baliwatu niemieckiego istnieje również baliwat austryjacki, w którego skład wchodzą komturie An der Drau i Am Inn und Hohen Rhein ${ }^{62}$.

Familiaren zajmują się szeroko pojętą działalnością wśród świeckich. Pracują w szpitalach, uczą, szerzą Słowo Boże i biorą czynny udział we wspólnocie kościelnej oraz mają obowiązek prezentować postawę godną do naśladowania.

Inną instytucją działającą $\mathrm{w}$ obrębie Zakonu jest powstała w lipcu 1991 roku Fundacja Zakonu Niemieckiego - Deutschordenstiftung z siedzibą w Vaduz w księstwie Lichtenstein. Jej działalność widać przede wszystkim na terenach objętych wojną, np. na terenie byłej Jugosławii, gdzie zajmowała się ona dostarczaniem żywności i leków oraz uciekinierami z byłej Bośni i Słowenii oraz w odbudowie zniszczeń wojennych ${ }^{63}$.

W Wiedniu znajduje się aktualnie centralne archiwum Zakonu, które posiada dokumenty z dziejów Zakonu Niemieckiego od końca XII wieku, a więc prawie od czasów jego powstania aż do dziś. Nie jest to zbiór wszystkich dokumentów Zakonu, gdyż duża ich część znajduje się w innych krajach, między innym w Polsce, w Archiwum Akt Dawnych w Warszawie, czy też w fundacji Preußischer Kulturbesitz w Berlinie. W pierwszej dekadzie XXI wieku dokumenty znajdujące się w Centralnym Archiwum Zakonu Niemieckiego w Wiedniu zostały zdygitalizowane i umieszczone na stronie internetowej www. monasterium.net. Funkcjonuje również

\footnotetext{
${ }^{60}$ Ibidem.

${ }^{61}$ Ibidem, 2 listopada 2012.

${ }^{62}$ Ibidem.

${ }^{63}$ Z. Kowalska, op. cit., s. 76-77.
} 
muzeum zakonne - Schatzkammer, które można odwiedzać, a w ostatnich dziesięciu latach włączone zostało ono do ogólnoeuropejskiego projektu Noc Muzeów.

Trzy razy do roku ukazuje się gazeta Deutscher Orden (ZDO). Jest ona informatorem religijno-kulturalnym na temat zarówno aktualnych wydarzeń z życia Zakonu jak i jego historii. Pismo powstało w 1970 roku, jego inicjatorem był P. Dr. Klemens Wieser OT. Pismo zostało wydane z okazji święceń Wielkiego Mistrza Mariana Tumlera. Następnym redaktorem przez 24 lata był P. Gottfried Daum OT. Od 2002 roku pismo prowadzi Sr. Reinhilde Platter OT ${ }^{64}$. Pismo można otrzymywać w abonamencie. Trafia ono do Austrii, Niemiec, Włoch, Belgii, Czech, Słowacji, Słowenii, Polski, Szwajcarii, Hiszpanii, Szwecji, Anglii i Stanów Zjednoczonych.

Co funkcjonuje jeszcze z Zakonu Krzyżackiego w architekturze, co z jego przeszłości funkcjonuje w świadomości ludzi, jaki wpływ na dzisiejszy Zakon ma polityczno-ideologiczne wykorzystywanie jego obrazu w XIX i XX wieku? Te pytania postawione zostały w sierpniu 2008 roku na konferencji Międzynarodowej Historycznej Komisji do badań nad Zakonem Niemieckim, która odbyła się we współpracy z Muzeum w Malborku i Toruniu ${ }^{65}$.

Rok 2010 był rokiem szczególnym w pierwszej dekadzie XXI wieku dla Zakonu Niemieckiego. Większość wydarzeń wiązała się z obchodami 600-lecia bitwy pod Grunwaldem. Z tego też powodu odbyły się liczne spotkania, konferencje i sympozja. W maju 2010 roku odbyło się sympozjum pod nazwą Tannenberg 1410. Dla Zakonu Niemieckiego utrata terytorium podczas bitwy była mniejszą stratą niż poważna strata jednej trzeciej rycerzy i miana niezwyciężonych. Bitwa pod Grunwaldem nie ma w historii tylko znaczenia militarnego, lecz przede wszystkim jest symbolem i często środkiem propagandy. Podczas sympozjum, w którym brał udział Wielki Mistrz Zakonu dr Bruno Platter oraz wielu znakomitych naukowców z Europy zwrócono uwagę na stereotypowe patrzenie na historię Zakonu poprzez pryzmat powieści historycznej Krzyżacy Henryka Sienkiewicza. Zaznaczono, iż bitwa jako przerażające wydarzenie powinna być ostrzeżeniem, ale jednocześnie historia Zakonu Niemieckiego powinna być ukazywana w sposób obiektywny ${ }^{66}$. Najważniejszym wydarzeniem 2010 roku było spotkanie Wielkiego Mistrza Zakonu Bruno Plattera z Prezydentem Rzeczpospolitej Bronisławem Komorowskim, z Prezydentem Parlamentu Europejskiego Jerzym Buzkiem oraz z Prezydent Litwy Dalią Grybauskaite i innymi przedstawicielami państw europejskich na

\footnotetext{
${ }^{64} \mathrm{http}: / /$ www.deutscher-orden.de, 13 listopada 2012.

${ }^{65}$ Ibidem, 17 listopada 2012.

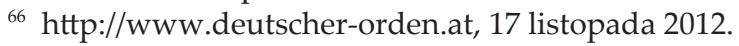


polach Grunwaldu. Jak zaznaczają Zakonnicy w opisie spotkania, zainscenizowana bitwa była jedynie symbolem tamtych odległych czasów, przedstawioną w sposób obiektywny ${ }^{67}$.

Działalność Zakonu Niemieckiego w pierwszej połowie XXI wieku jest bardzo prężna i widoczna na terenach nie tylko państw niemieckiego obszaru językowego ale także w całej Europie. Osoby mające do czynienia z działalnością Zakonu nie patrzą już na niego przez pryzmat bitwy pod Grunwaldem, lecz widzą jego zaangażowanie w życie społeczne i życie Kościoła oraz pozytywne skutki jego działalności.

\section{Zusammenfassung}

Der Orden der Brüder vom Deutschen Haus Sankt Mariens in Jerusalem, kurz Deutscher Orden, ist ein katholisches, klerikales Institut, das aufgrund des päpstlichen Rechtes das Apostolat führt. Der Deutsche Orden führt heute seine Tätigkeit nicht nur in der Pflege von Kranken, Armen und Alten sondern auch in der christlichen Erziehung und Bildung von Kindern, Jugendlichen und Erwachsenen aus. Brüder, Schwestern und Familiare, die zusammenarbeiten, haben als Ziel, zum Aufbau des Reiches Gottes beizutragen. Brüder und Schwestern verteilen sich auf Provinzen und die Familiaren gliedern sich in Balleien und in die selbständige Komturei. Die Familiaren Deutschlands funktionieren als der eingetragene Verein Deutschherrenbund. Das Institut der Familiaren ist dem Orden geistlich angegliedert und besteht vor allem aus Laien, die keine Ordensgelübde ablegen.

Menschen, die daran Interesse haben, können die Schatzkammer besuchen und die Zeitschrift Deutscher Orden abonnieren. Tätig ist auch eine Internationale Historische Kommission zur Erforschung des Deutschen Ordens, die mit der wissenschaftlichen Erforschung der Geschichte des Deutschen Ordens von den Anfängen bis zur Gegenwart beschäftigt ist.

${ }^{67}$ Ibidem, 17 listopada 2012. 